\title{
Lost Grains and Forgotten Vegetables from Japan: the Seikei Zusetsu Agricultural Catalog (1793-1804)
}

\author{
Shantonu Abe ChatterjeE ${ }^{1,2}$ And Tinde van Andel A,2,3,4 $^{2}$ \\ ${ }^{1}$ University of Cologne, Cologne, Germany \\ ${ }^{2}$ Biosystematics Group, Wageningen University, Wageningen, The Netherlands \\ ${ }^{3}$ Naturalis Biodiversity Center, Leiden, The Netherlands \\ ${ }^{4}$ Clusius Chair in History of Botany and Gardens, Leiden University, Leiden, The Netherlands \\ *Corresponding author; e-mail: tinde.vanandel@naturalis.nl
}

\begin{abstract}
Historic illustrations represent interesting source material for the study of traditional crop varieties that have not been described in the literature or safeguarded in germplasm institutes or botanic gardens. Here, we present the crop diversity depicted on 143 illustrated pages of the 30-volume Seikei Zusetsu agricultural catalog, compiled in Japan around 1800 and gifted to the Dutch East India Company physician and naturalist Philipp Franz Von Siebold (1796-1866). We identified 109 different species of crops and wild edible plants in the catalog, in which cereals were represented with 35 different varieties and Brassicaceae with 29 varieties of turnips, cabbages, and radishes. We published all images online, with translations of the historic Kanji and Katakana names, of which 103 included ancient Dutch crop names. Less than half of these early nineteenth-century crop species are still grown in substantial quantities in Japan today, although some may have survived in home gardens. The Seikei Zusetsu catalog is a valuable repository of traditional Japanese knowledge on crops, agricultural practices, and food processing methods and could stimulate efforts to create more agrobiodiverse farming systems and the marketing of high-value crops to ensure the survival of distinctive food cultures.
\end{abstract}

日本の失われた穀物、忘れられた野菜：成形図説農書（1793-1804). 現存する作物の図解記 録の資料には、食用作物の多樣性に関するジーンバンクゃ植物園では保存しきれない情報と種 類を読み取る可能性がある。この論文では植物学者シーボルト(Philipp Franz Von Siebold 1796-1866)に島津藩より贈与された「成形図説」原本を基に食用植物の多樣性を分 析している。1 800 年頃に編集が完成した 30 巻のうち分析対象となった植物画は計 143 図。これらは栽培種と野生種を含む109品種に分類され、ことに多かつたのはコメ、アワ等を 含むイネ科の35件と、カブ、ダイコン等を含むアブラナ科の 29 件であった。全ての図をインタ 一ネット上に公開し、付記情報として古典和名、学名、英語名、日本語名を記 載した。うち103件は蘭学に基づくオランダ語名(蕃名)もカタカナで表記されていたのでオランダ 語に翻訳した。19世紀初頭に記録されたこれらの食用作物のうち、現代日本で伝統野菜として 家庭菜園では栽培されているものもあるかも知れないが、農林水産省統計で確認できる作物は半 分以下であつた。植物の栽培方法や利用方法も今後読み解いていけば、伝統的知識の宝 庫として、また植物図の美しさも相まって「成形図説」の果たす役割は大い。今日、生物多樣 性の重要さが見直されている中、このような記録は生態系に根ざした多樣性に富んだ農 業システムの提案や、貴重な食文化の継承に帰する市場価值のある食用作物の認知にも貢 献できるものと期待される。

\footnotetext{
${ }^{1}$ Received 7 October 2018; accepted 2 July 2019; published online 26 August 2019

Electronic supplementary material The online version of this article (https://doi.org/10.1007/s12231-01909466-z) contains supplementary material, which is available to authorized users.
} 
Key Words: Agrodiversity, historic crop varieties, landraces, traditional agriculture, Von Siebold.

\section{Introduction}

Improving crop diversity is seen increasingly as a way to address the changing agenda of agricultural production, which calls for more resilience to climatic changes and the ability to provide better nutritional outcomes. In the last century, agriculture has seen a steady decline in genetic diversity (Casals et al. 2017; Oldfield and Alcorn 1991) and an increasing dependence on intensive mono-cropping systems with crop cultivars selected for optimal performance in controlled, uniform conditions maintained through the heavy use of input nutrients and energy (Rutto et al. 2016). While yields have increased under this paradigm, it has come at the cost of a declining diversity of crops eaten, resulting in a highly homogenized global diet (Khoury et al. 2014) and a reduced capability to react to sub-optimal conditions such as climate change, low inputs, pests, and disease, or other unexpected shocks to the system (Liebman and Schulte 2015; Lin 2011). Agricultural systems are nowadays dominated by a limited number of cultivars, developed by plant breeding companies, and selected for high yield, phenotypic uniformity, and genetic stability (Zeven 1998).

Before the development of commercial plant breeding, all cultivated plants were landraces: crop varieties selected by farmers themselves and adapted to local environmental circumstances. Landraces are less uniform and may have intermediate yields under low-input agricultural systems, but generally have a high capacity to tolerate biotic and abiotic stresses (Villa et al. 2005). Their huge genetic diversity makes them valuable genetic resources to complement and diversify the gene pool of advanced cultivars (Rutto et al. 2016).

Many landraces that were not safeguarded appropriately in germplasm banks, conservation programs, or botanic gardens have already been lost (Casals et al. 2017). Most researchers on historic crop varieties study living and conserved plant material or descriptions in botanical and agricultural literature. Historic paintings and illustrations also represent interesting source material, as they show crop varieties that are either not described or scantly mentioned in the contemporary literature. Scientists have discovered lost landraces of cabbage and wheat in early modern Dutch and Flemish paintings (Zeven and Brandenburg 1986) and ancient varieties of grapes and cereals on the eighteenthcentury Sicilian drawings (Mazzola et al. 2003). In this paper, we present the crop diversity depicted on 143 illustrated pages of a Japanese agricultural catalog produced around 1800 .

\section{The Seikei Zusetsu Catalog}

The library of the Netherlands' Leiden University holds a valuable and rare Japanese agricultural encyclopedia (Special Collections, Serrurier collection, Ser. 1042), compiled in the 1793-1804 period. This 30volume catalog is a comprehensive encyclopedic treatise on Japanese agriculture, illustrated with a large variety of crop species and varieties (Fig. 1). This socalled Seikei Zusetsu catalog was once owned by the German physician Philipp Franz von Siebold (1796-1866). Employed by the Dutch East India Company (VOC) in the trading post in Dejima near Nagasaki, von Siebold became famous for the introduction of Western medicine in Japan and his studies of the local flora and fauna (Kauffmann Jokl and Hiyama 2003). During his stay in Japan (1823-1829), he accumulated a collection of more than 1,000 books, ethnographic artifacts, natural history collections, and living plants for the purpose of increasing the Dutch understanding of the enigmatic Japanese nation. Many of these artifacts were given to him in exchange for his scientific lectures and surgical demonstrations (Kauffmann Jokl and Hiyama 2003). The value of this vast collection, which is kept at various institutes in Leiden, lies not only in their rarity, but also because they represented a curated collection of state-of-the-art knowledge in Japan at the time (Brown 1975).

The 30 printed volumes of the Seikei Zusetsu contain an encyclopedic explanation of the various crops-vegetables, herbs, and trees-their properties and characteristics, their utility for humans, and the best systems to cultivate them. Still, only a few studies have been carried out about this catalog. In his book The Knowledge of Nature and the Nature of Knowledge in Early Modern Japan, Marcon (2015) discussed the various knowledge systems used in describing nature in the Seikei Zusetsu and explains the significance of this work as a representation of the openness to "outside knowledge" in a period marked by isolationism. Fukuoka (2012) studied the encyclopedia for contemporary 


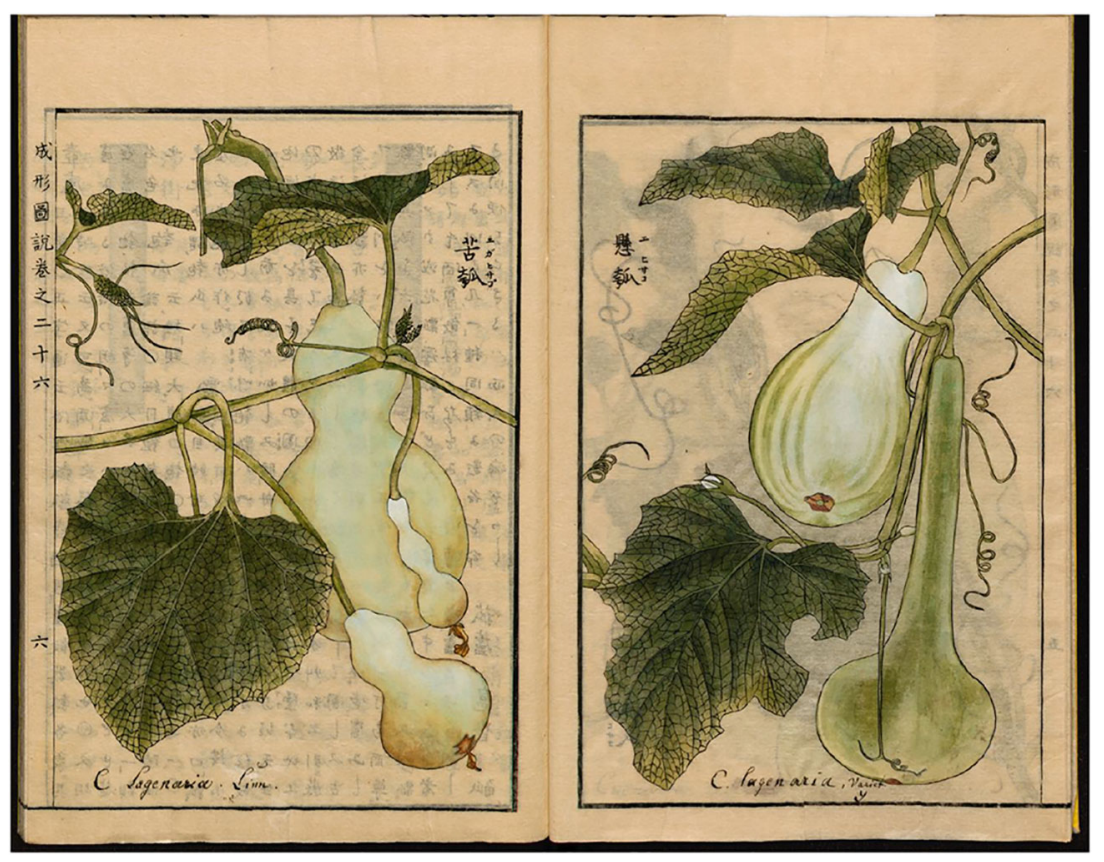

Fig. 1. Illustration of several varieties of bottle gourd (Lagenaria siceraria (Molina) Standl.) in the Seikei Zusetsu catalog (vol. 26, pp. 5-6).

representations of the "truth" (shin, 真) in pictorial representations and provides insight into the science of visual representations during this period. What is lacking, however, is a systematic inventory of all crop species and varieties illustrated in the catalog. Such an inventory will help to gain a better understanding of the diversity of crops in the farming systems of the Tokugawa or Edo period in Japan (1603-1868). It will also allow a comparison with present-day crop diversity on Japanese farms.

After a brief description of the Seikei Zusetsu cata$\log$, we provide answers to the following research questions: (1) Which crop species, varieties, and local names are mentioned in the catalog? (2) How many of these species and varieties are still grown in Japan and can be considered "forgotten vegetables?" (3) What is the scientific relevance of the Seikei Zusetsu today?

With the online dissemination of the early nineteenth-century, hand-painted illustrations, their scientific names, and the translation of the local names, we aim to draw the attention of scientists and the general public in and outside Japan to this magnificent catalog. We hope to create renewed interest in these underutilized and possibly forgotten crops of Japan and stimulate their future use in sustainable agriculture.

\section{Methods}

All illustrations of crop specimens in the 30volume Seikei Zusetsu catalog were digitized as high-resolution images and uploaded on the digital repository of the Leiden University Library Special Collections. A spreadsheet was created of all crop illustrations, historic names in Kanji and Katakana characters, historic Latin binomials, and Dutch names written on the pages as well as current Kanji and Katakana names with translation and current scientific identifications. We identified the depicted species by using the handwritten identifications on the pages, the literature on Japanese agriculture (Aoba 1981, 2013; Otake 2009a, b), the PROSEA Series (1992-2003) with botanical descriptions of useful plants in Southeast Asia and the Internet. Pulses and Cucurbitaceae were identified by botanical specialists at Naturalis Biodiversity Center (L), Leiden. Scientific names were checked using The Plant List (www.theplantlist.org). For every illustration, the meaning of the Kanji characters was given in English to facilitate the understanding of the local nomenclature. A transliteration of the Japanese Katakana script was also provided to aid pronunciation of the Japanese names. We transcribed Dutch plant names in Katakana script and checked the historic 
Dutch names with the PLAND database on plant names in the many Dutch dialects (http://www. meertens.knaw.nl/pland/) and the English translation by Beekman (2011) of the Herbarium Amboinense (Rumphius 1741-1750), a six-volume work on useful plants in the Moluccas Islands (also called the Maluku Islands). We translated them into current Dutch and added common English names. To verify how many crops from the Seikei Zusetsu are currently being cultivated in Japan, a comparison was done with literature (e.g., Aoba 2013) and online data obtained from the Ministry of Agriculture, Forestry and Fisheries (MAFF 2016a, b) on Japanese agriculture between 1966 and 2014, which we plotted in graphs.

\section{Results}

\section{History of the Seikei Zusetsu Catalog}

The extensively illustrated, 30-volume agricultural encyclopedia was commissioned by Shimazu Shigehide (島津重豪 1745-1833), ruler of the Satsuma domain, a province in southern Japan roughly corresponding to the current Kagoshima prefecture. The compilation of this comprehensive encyclopedia started in Osaka in 1793, through a collaborative effort by a team of scholars hired for this purpose. Because of its multiple authors, the encyclopedia is influenced by several scientific trends. For example, Kokugaku (国学), a Japanese nativist movement in academic studies during the Edo period (Burns et al. 2007); Confucian studies, representing the Chinese education within academic circles (Nosco 1998); and Rangaku (蘭学), literally translated as "Dutch Studies," representing botany, zoology, geography, anthropology, and medicine (Kauffmann Jokl and Hiyama 2003) or the broader category of Western academic knowledge (Van Sant 2012). The purpose of this agricultural encyclopedia was to provide a source of information for improving agricultural production in Southern Japan by expansion, diversification, and maximization of agricultural production (Marcon 2015).

Although the original encyclopedia consisted of 100 volumes at the time of completion of the wooden printing blocks, 70 of these were destroyed in two major fires (1806 and 1829), leaving only 30 volumes to be published (Marcon 2015). The current version consists of 30 small booklets $(19.7 \times$
$26.5 \mathrm{~cm}$ ), printed on thin rice paper, uniformly bound in stiff yellow stitched wrappers (Fig. 2). The contents are texts in Japanese, and the illustrations show agricultural ceremonies, festivals, planting, and irrigation methods, flood control, farm tools, pest control, and a large number of crop varieties.

The online bookstore Biblio.com offers a blackand-white copy of the entire catalog for USD 16,597 (https://www.biblio.com/book/seikeizusetsu-illustrated-book-agriculture-woodblock/d/ 864907648). According to Biblio.com, the fires also ruined a great number of the printed pages. The company claims its catalog as "a very rare set, seldom found" and a "rare first and only edition." However, another black-and-white copy of the entire Seikei Zusetsu catalog, owned by the University of Michigan, is made available online by the Hathi Trust Digital Library in Ann Arbor, Michigan, USA (https://catalog.hathitrust.org/Record/ 002296968). A second complete digital copy is accessible through the National Diet Library Digital Collection in Japan (http://dl.ndl.go.jp/info:ndljp/ $\mathrm{pid} / 2546029$, in Japanese). The latter is a colored edition, but the colors are less bright than the Leiden volumes.

What makes the Leiden copy of Seikei Zusetsu's agricultural encyclopedia unique is not only its vivid colors, but also the fact that Katsuragawa Hoken signed it with his Japanese name and his Dutch name ("Wilhelmus Botanicus"), suggesting that the books were a gift from him to von Siebold. Shigehide, the commissioner of the book, also met with von Siebold in April 1826, and talked with him about his love for the study of natural history (Matsui 1975).

\section{Online Access to the Seikei Zusetsu Crop Illustrations}

The Seikei Zusetsu catalog contains 143 illustrated pages with crops, with a total of 193 drawings of individual crop varieties. Each illustration is accompanied with a name in Kanji characters to indicate the commonly used Chinese name of each specific crop variety and its name in Katakana characters that represent its commonly used Japanese name. Some of the illustrations, like the one of Colocasia esculenta (L.) Schott (Fig. 3), have been annotated with binomial names. This handwritten text was most likely added by von Siebold or by one of his students. These Latin names are not present in the black-and-white copy published online by the 


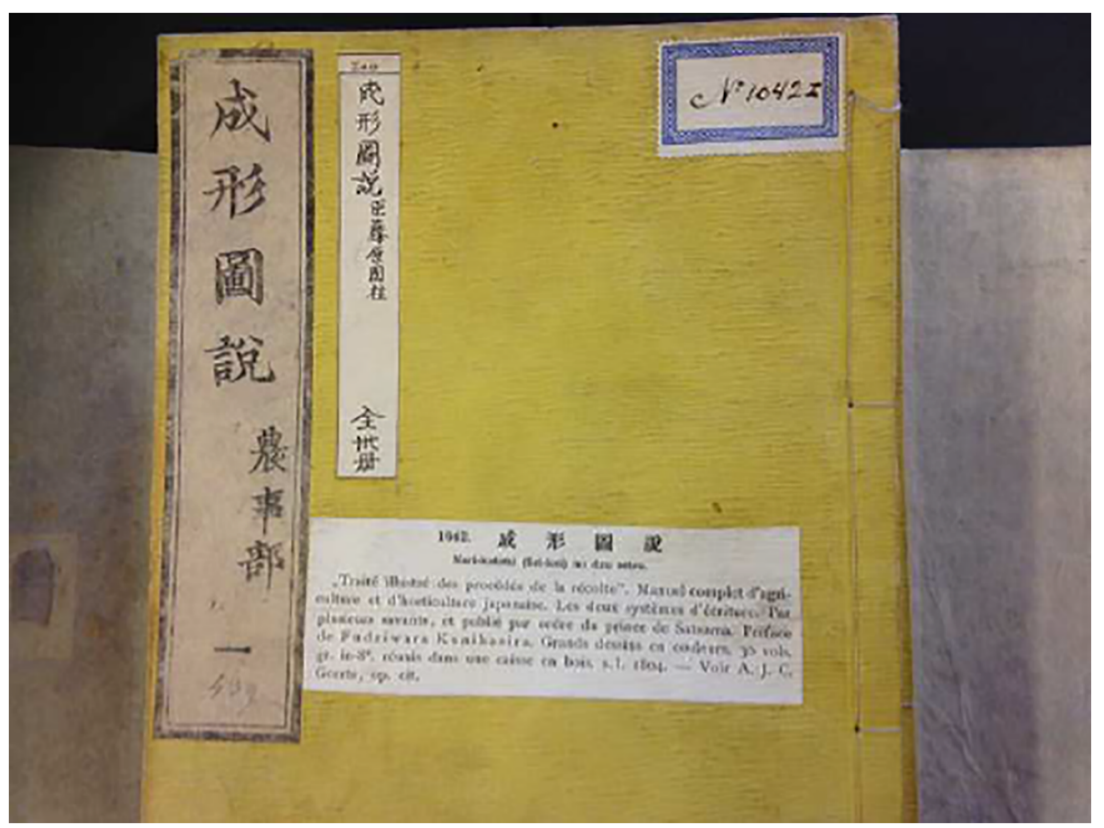

Fig. 2. Cover of one of the 30 volumes of the Seikei Zusetsu catalog in the Special Collections of the Leiden University Library.

Hathi Trust Library or the color version on the website of the Japanese National Diet Library.

All 143 illustrated pages can be viewed online at the Special Collections repository of the Leiden University Library, with their local and current scientific names: https://digitalcollections. universiteitleiden.nl/japanese_agriculture_19th_ century. To zoom in, download or view the associated information, click on the image. The complete list of cultivars and their associated information (local names, transcriptions and translations, current scientific names) is also provided in this paper's ESM 1(Electronic Supplementary Material), following the order of the website when sorted on title. The remaining pages of the Leiden catalog have not (yet) been digitized or translated into English.

\section{Diversity of Crop Species and Varieties}

The parts of the Seikei Zusetsu catalog that describe individual crops (vols. 15 to 30 ) are divided into two sections. The first lists the "five cereal crops" (五穀部, itsutsu-no-tanatsu-mono section, vols. 15-20) that groups the major cereal crops and pulses together, as beans were staple grains in Japanese historical documents (Yabuno 1987). The second part is devoted to the "vegetables"
(蔬菜部, sosai section, vols. 21-30), in which other crops and wild edible plants are described. A total of 109 distinct crop species are depicted, belonging to 29 different plant families, of which the most diverse are the Poaceae with images of 35 different varieties and the Brassicaceae, with 29 illustrated varieties (Fig. 4). Nine plant families are represented with just one crop species each.

Of the 109 crop species, 84 are represented in the catalog by a single variety. Some species, however, are represented by many varieties, such as the daikon radish (Raphanus raphanistrum subsp. sativus (L.) Domin), turnips (Brassica rapa L.), and rice (Oryza sativa L.). The catalog also lists a remarkable number of millet species and varieties, such as foxtail millet (Setaria italica (L.) P. Beauv.), proso millet (Panicum miliaceum L.), and Japanese barnyard millet (Echinochloa esculenta (A.Braun) H.Scholz), suggesting that these grains were of similar importance as rice in the Japanese diet around 1800. As little information on the identification of specific varieties is provided in the botanical literature or on the Internet, we have followed the distinction of the varieties of the Seikei Zusetsu catalog itself. Figure 5 shows the number of illustrations per species, which generally corresponds to the amount 


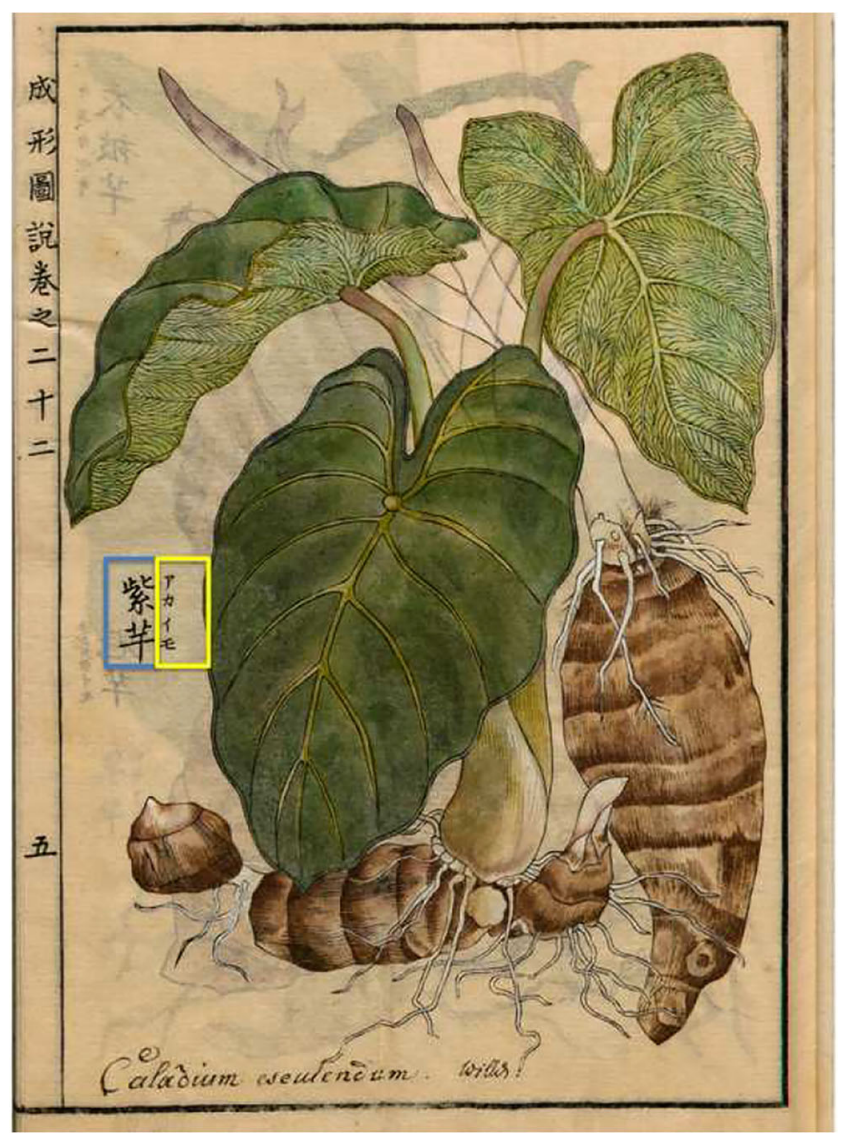

Fig. 3. Illustration of 'Caladium esculendum Willer' (Colocasia esculenta) in vol. 22, p. 5 of the Seikei Zusetsu catalog, with names in Kanji (blue rectangle), Katakana (yellow rectangle), and Latin (below).

of varieties. In some cases, however, illustrations represent typical mutations or different parts of useful plants. Examples are the double-headed rice (Seikei Zusetsu catalog vol. 15, p. 22), a branching mutant of Oryza sativa, and the case of lotus (Nelumbo nucifera Gaertn.), where details on each edible part of the lotus plant are depicted separately.

Some illustrations are meant to show the difference between the crop and later generations of accidentally self-sown crops after the first harvest. Examples are the illustrations of the "grandchild of the rice" and secondary growth rice (Seikei Zusetsu catalog vol. 16, page 40), which depicts shorter rice plants with spreading or few-seeded panicles. These result from sprouted seeds that fell during the last harvest or from spontaneous crossings between different varieties.

There is also an illustration of a second growth soybean (Seikei Zusetsu catalog vol. 18, p. 23), a less sturdy, self-sown progeny of the soybean (Glycine $\max ($ L.) Merr.). Some illustrations serve to distinguish the desired crop from imposters, similarlooking wild crop relatives that grow as weeds between crops, such as wild foxtail millet (Setaria viridis (L.) P. Beauv., Seikei Zusetsu catalog vol. 19, p. 4) and big barley imposter (Triticum monococcum L., Seikei Zusetsu catalog vol. 17, p. 4). Finally, a drawing of the wheat imposter (Ustilago nuda (C.N. Jensen) Rostr., Seikei Zusetsu catalog vol. 17, p. 14) shows a common fungal disease that replaces the grain heads with masses of spores that infect the open flowers of healthy plants and grow into the seed.

A striking aspect of the catalog is the diversity of lily species depicted in the catalog. Around 1800 lily bulbs and flowers in Japan were primarily considered to be vegetables. The bulbs were consumed fresh, dried, or boiled and both cultivated, like the 


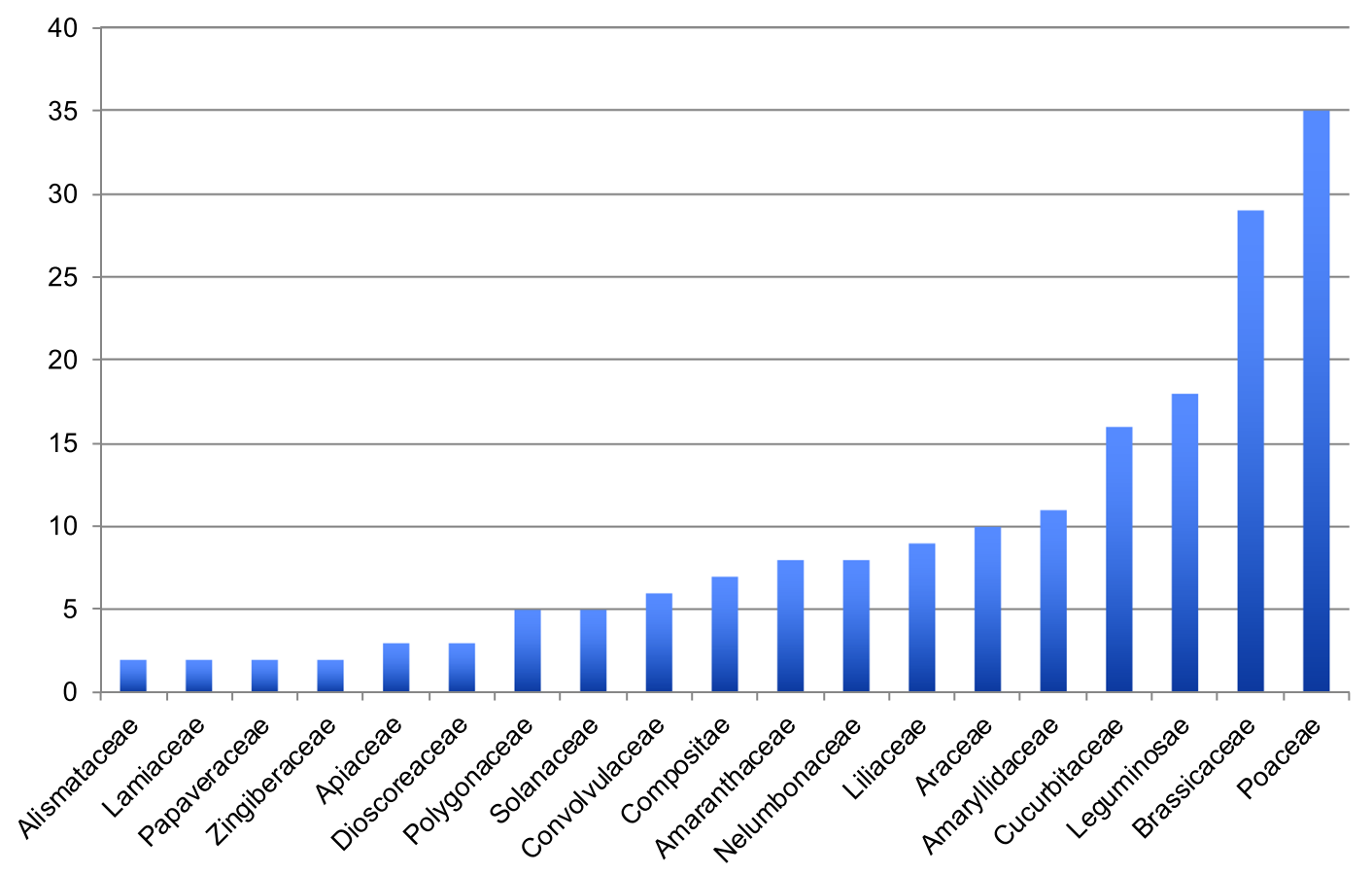

Fig. 4. Number of illustrations per plant family in the Seikei Zusetsu catalog. Each illustration represents a distinct crop variety. Only families with more than one illustration are shown.

early-domesticated tiger lily (Lilium lancifolium Thunb., Seikei Zusetsu catalog vol. 30, p. 26) or harvested from the wild, such as Lilium longiflorum Thunb. (Shimizu 1987; Simoons 1990). In the Western world, lilies nowadays are known mainly as attractive ornamentals, although Native Americans also consumed many species of lily bulbs in the past (Elias and Dykeman 2009). Volume 30 of the catalog also lists several other vegetables that were probably collected in the wild, such as shepherd's purse (Capsella bursa-pastoris (L.) Medik.), bracken (Pteridium aquilinum (L.) Kuhn), and common horsetail (Equisetum arvense L.).

\section{Local Names Referring to Geographical ORIGIN}

Several varieties in the Seikei Zusetsu catalog are described with Kanji names that refer to a particular geographic origin (Table 1). Specifically, the radishes and the turnips are linked to a specific Japanese island, volcano, city, or even a town neighborhood. The Bohai eggplant (Solanum melongena L., Seikei Zusetsu catalog vol. 26, p. 27) may have been introduced to Japan from the surroundings of the Bohai sea (near Beijing, China), while Sichuan sorghum (Sorghum bicolor (L.) Moench, Seikei Zusetsu catalog vol. 19, p. 17) and maize, then known as Bead Sichuan Sorghum (Zea mays L., Seikei Zusetsu catalog vol. 19, p. 19) may have entered Japan via the Chinese Sichuan area.

Several of the early nineteenth-century crop names indicate general geographic origins, such as south or west. The directions east and north are rarely used, given Japan's position in the Far East and the fact that few crops grow north of Hokkaido. The Chinese character is used in some names, which suggests areas to the north and the west of China. Other names refer to varying degrees of exoticness, from foreign to barbarian. The character is often used in Japan as a way of denoting something of foreign, usually Western origin. The name po lang grass for spinach (Spinacia oleracea L.) is explained by Beal (2000: 135) as originating from the ancient country of Po-Lu-Lo or Bolor (菠蓤) in the Himalayas, possibly indicating Tibet. Its local name suggests that this crop, although originating in central and western Asia, came to China and 


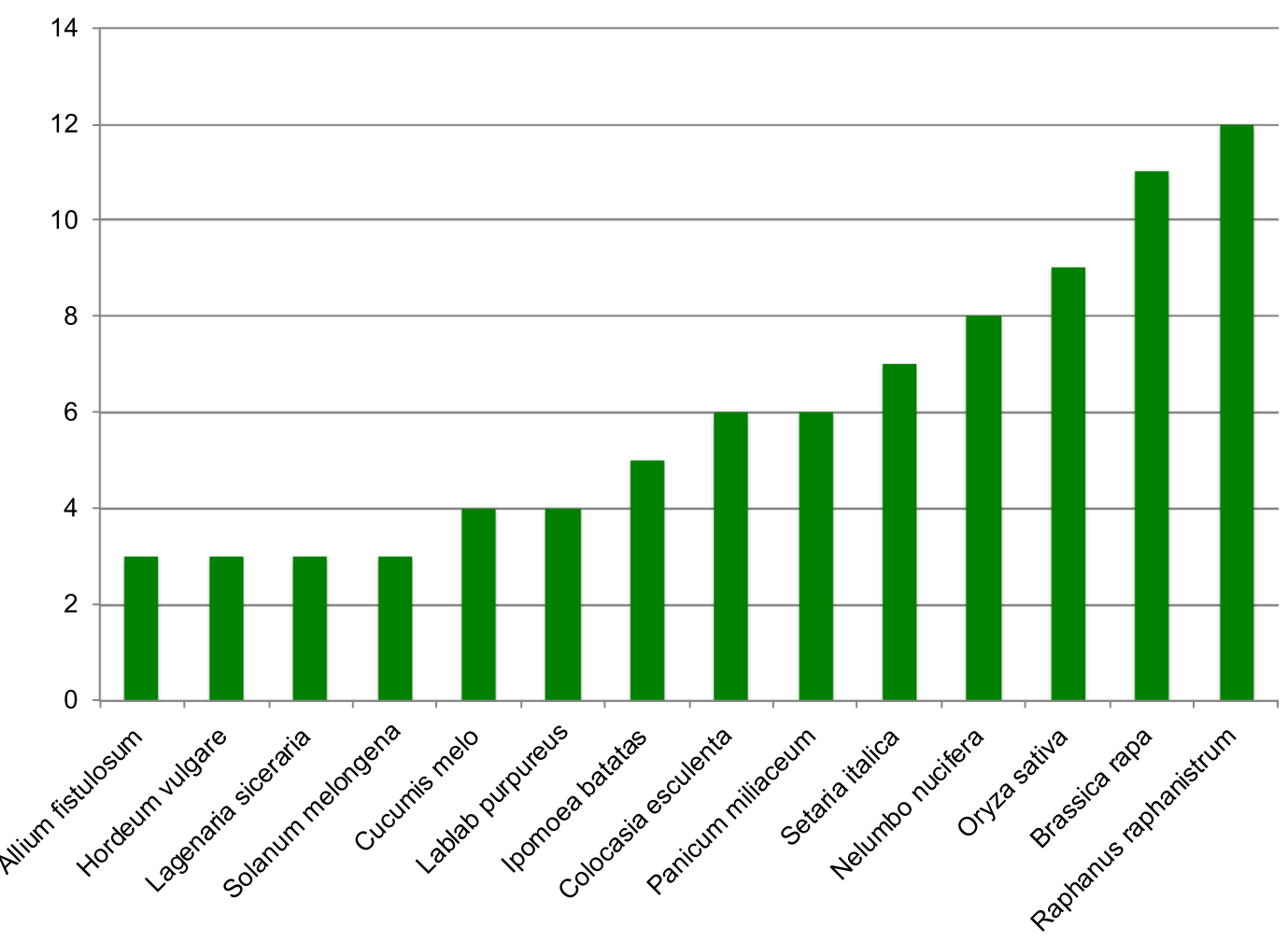

Fig. 5. Number of illustrations per species in the Seikei Zusetsu catalog. Only species with more than two illustrations are shown.

Japan via the Indian subcontinent during the Tang Dynasty (618-907), and probably taken to Japan with its name distorted on the way. Some of these local names are preserved today in modern cultivars, such as the Sakurajima daikon (Seikei Zusetsu catalog vol. 21, p. 21; Fig. 6a), although the morphology of this radish variety has changed dramatically since 1800 (Fig. 6b). At present, modern cultivars of the round Sakurajima are marketed as the largest radish in the world (https://www.rareseeds.com/sakurajima-radish).

\section{Local Names IN Dutch}

Some of the crops listed in the Seikei Zusetsu catalog are also accompanied by a reference within the text of the foreign name (hanmei, 蕃名), which is the Dutch name of the crop written down in Katakana script. A total of 103 plant illustrations contained in the Seikei Zusetsu catalog are given Dutch names (ESM 2), most likely provided by Rangaku scholars who were using Dutch plant books as references. It is not clear on which sources these local Dutch names are based, as the Seikei Zusetsu catalog was produced before 1823, when von Siebold came to Japan. A potential source for these Dutch plant names could have been the Swedish botanist and physician Carl Peter Thunberg (1743-1828), who stayed in Japan for 16 months. He traveled to Asia as a surgeon with the Dutch East India Company, but his objective was to collect botanical specimens for botanical gardens in the Netherlands (Skuncke 2014). He stayed for 3 years in the Cape (South Africa) to learn Dutch and visited Dutch colonial areas in Indonesia and Sri Lanka. According to (Marcon 2015: 137), "Thunberg's intellectual exchange with Japanese scholars hardly left any trace in Japan," but Skuncke (2014) proves that Thunberg shared medical and botanical knowledge with his Japanese counterparts. He exchanged information on Latin and Dutch names and uses of crops for their Japanese names. It is known that Japanese scholars circulated seventeenth-century illustrated Dutch herbals, 
Table 1. Geographical origins of crop varieties reflected in their Kanji names in the Seikei Zusetsu CATALOG.

\begin{tabular}{|c|c|c|c|}
\hline Book: page & Kanji names & English name & Scientific Name \\
\hline $19: 17$ & 玉蜀㯟 & Bead Sichuan sorghum & Zea mays L. \\
\hline $20: 11$ & 胡麻 & Foreign hemp & Sesamum indicum $\mathrm{L}$. \\
\hline $21: 20$ & 宮重葍 & Miyashige radish ${ }^{1}$ & Raphanus raphanistrum ssp. sativus (L.) Domin \\
\hline $21: 21$ & 櫻島葍 & Sakurashima ${ }^{2}$ radish & Raphanus raphanistrum ssp. sativus (L.) Domin \\
\hline $21: 21$ & 倉梯葍 & Kurahashi $^{3}$ radish & Raphanus raphanistrum ssp. sativus (L.) Domin \\
\hline $21: 22$ & 葛畑葍 & Kusuhata $^{4}$ radish & Raphanus raphanistrum ssp. sativus (L.) Domin \\
\hline $21: 22$ & 秦野葍 & Hadano ${ }^{5}$ radish & Raphanus raphanistrum ssp. sativus (L.) Domin \\
\hline $21: 23$ & 䇾原葍 & Minobaru $^{6}$ radish & Raphanus raphanistrum ssp. sativus (L.) Domin \\
\hline $21: 33$ & 近江無 & Oumi $^{7}$ turnip & Brassica rapa $\mathrm{L}$. \\
\hline $21: 33$ & 品川無 & Shinagawa ${ }^{8}$ turnip & Brassica rapa $\mathrm{L}$. \\
\hline $21: 34$ & 難波無 & $\mathrm{Namba}^{9}$ turnip & Brassica rapa $\mathrm{L}$. \\
\hline $21: 34$ & 仲川無 & Nakatsukaha ${ }^{10}$ turnip & Brassica rapa $\mathrm{L}$. \\
\hline $23: 03$ & 胡蘿蓄 & Foreign radish turnip & Daucus carota $\mathrm{L}$. \\
\hline $23: 24$ & 菠薐草 & Po lang ${ }^{11}$ grass & Spinacia oleracea L \\
\hline $24: 08$ & 胡葱 & Foreign leek & Allium schoenoprasum $\mathrm{L}$. \\
\hline $25: 18$ & 蕃椒 & Foreign pepper & Capsicum annuum $\mathrm{L}$. \\
\hline $26: 17$ & 胡瓜 & Foreign gourd & Cucumis sativus $\mathrm{L}$. \\
\hline $26: 27$ & 渤海茄 & Bohai ${ }^{12}$ eggplant & Solanum melongena L. \\
\hline $27: 04$ & 越瓜 & Vietnam gourd & Cucumis melo $\mathrm{L}$. \\
\hline $27: 17$ & 南瓜 & South gourd & Cucurbita pepo L. \\
\hline $27: 17$ & 番南瓜 & Barbarian south gourd & Cucurbita maxima Duchesne \\
\hline $27: 18$ & 西瓜 & West gourd & Citrullus lanatus (Thunb.) Matsum. \& Nakai \\
\hline
\end{tabular}

${ }^{1}$ Miyashige village in Sudo city, Aichi Prefecture, West Japan

${ }^{2}$ Sakurajima volcano in Kagoshima Prefecture, South Japan

${ }^{3}$ Kurahashi village, Toyonaka City, Osaka Prefecture, West Japan

${ }^{4}$ Kusuhata: Former place name, possibly in Kagoshima Prefecture (South Japan) or in Osaka Prefecture (West Japan)

${ }^{5}$ Hatano city in Kanagawa prefecture, Central Japan

${ }^{6}$ Minobaru village in Miyakonojo City, Miyazaki Prefecture, South Japan

${ }^{7}$ Old name of Shiga Prefecture, West Japan

${ }^{8}$ Shinagawa city of Tokyo Prefecture, Central Japan

${ }^{9}$ Namba District, Osaka Prefecture, West Japan

${ }^{10}$ Nakatuskaha, usually Nakagawa in Japanese. Common-place name, difficult to ascertain the exact location

${ }^{11}$ Po lang. Etymology of the word is unclear, could refer to Iran or Tibet

${ }^{12}$ Bohai Sea in China, close to Beijing

such as Petrus Nylandt's Der Nederlandsche Herbarius of Kruydt-boeck (Nylandt 1673) and the 1644 edition of Rembert Dodoens's Cruijdeboeck (Marcon 2015; Skuncke 2014). Although Thunberg had studied the six volumes of Rumphius (1741-1750) on useful plants of the Moluccas, there is no evidence that a copy of this work was present in Japan (Skuncke 2014). The Swedish botanist published his Flora Japonica (Thunberg 1784), which was cited regularly by the person who wrote the Latin names on the Seikei Zusetsu illustrations, such as those of Lablab purpureus (L.) Sweet (vol. 18, p. 37) and Canavalia gladiata (Jacq.) DC. (vol. 18, p. 47). Von Siebold and his students must have used Thunberg's Flora Japonica extensively.
Apart from some authentic Dutch words for crops, such as bloemkool (cauliflower) and uien (onions), some of the Dutch crop names are no longer in use today, but seem to have been copied from historic Dutch herbals. In Dodoens (1644: 582-584), Amaranthus blitum subsp. oleraceus (L.) Costea is indicated as groot majer, a name given to Amaranthus tricolor L. in the Seikei Zusetsu. The lengthy descriptions in Dutch for unfamiliar crops, such as "grote langwerpige recht opstaande Braziliaanse peper," which can be translated as large, elongated, straight, erect Brazilian pepper for a variety of Capsicum annuum L. are also copied from Dodoens (1644: 1122-1126). Neotropical crops like hot pepper, maize, and potato (known around 1800 as fragrant yam, Seikei Zusetsu catalog vol. 

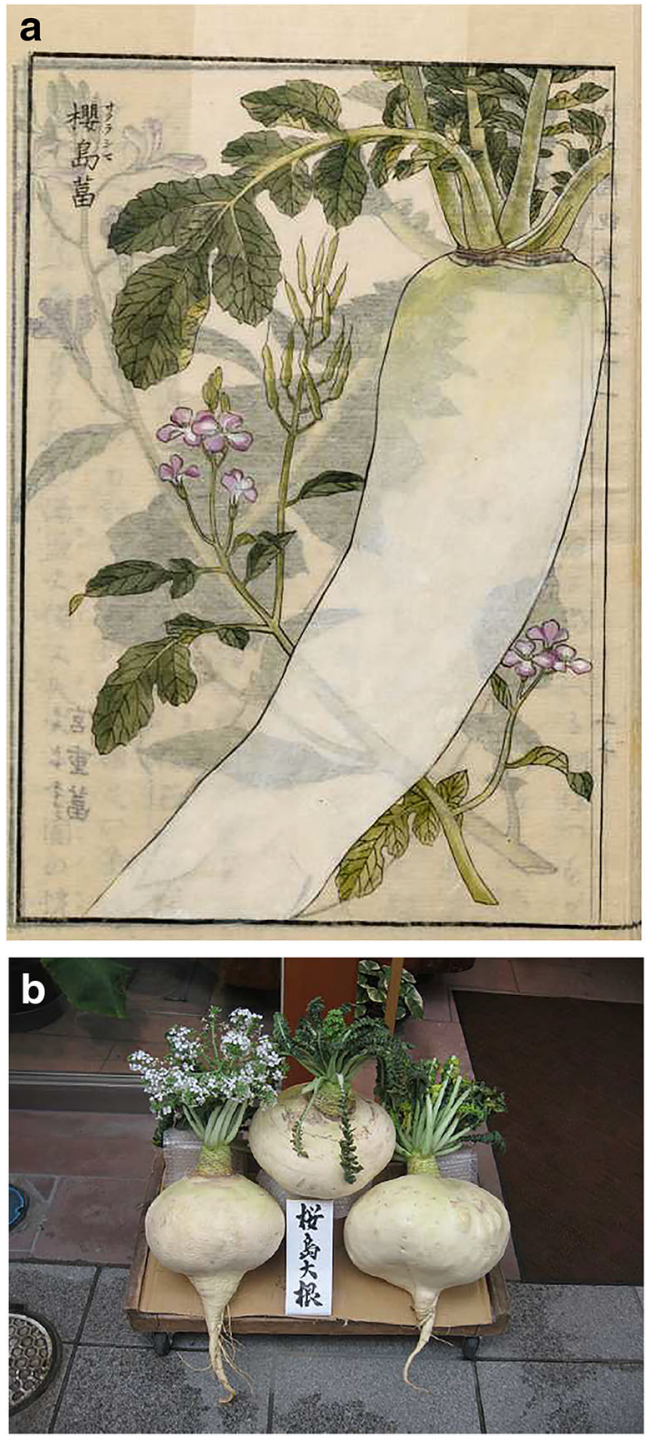

Fig. 6. A. Sakurajima daikon radish as pictured in the Seikei Zusetsu. B. The modern cultivar. Picture retrieved from https://commons.wikimedia.org/w/index.php? curid $=4585198$.

22, p. 32) were introduced to Japan as early as the sixteenth century by Dutch and Portuguese traders (Crosby 2003).

For 17 of these "Dutch names," the Katakana had corrupted the Dutch words to such an extent that we could not provide a complete translation and were unable to match them to the DutchMalayan plant names recorded by Rumphius in the Moluccas around 1700. For several species, the Dutch names were misidentifications, probably because the early Dutch herbals did not list many exotic Asian crops. Sesame (Sesamum indicum L.) carries the Dutch name lijnzaad, which refers to linseed (Linum usitatissimum L.). The Dutch name snijboon, used in the Netherlands for a flat-podded cultivar of Phaseolus vulgaris L. is given to the tropical legume Mucuna pruriens (L.) DC. in the Seikei Zusetsu catalog. The Dutch name waterruiterskruid (translated as water horsemanweed) is reserved in the Netherlands to Stratiotes aloides L. but here given to the Japanese aquatic plant Sagittaria trifolia L.

\section{Decline in Agricultural Production in JAPAN}

The Japanese Ministry of Agriculture, Forestry and Fisheries has collected data on the areas under cultivation of crops grown in significant amounts from 1966 to 2012 (MAFF 2016a, b; ESM 3 and 4 ). Of the 109 crop species described in the Seikei Zusetsu catalog, only 50 species are still cultivated to such an extent that the MAFF has data available on production area, with 24 species being classified as major crops and the remaining 26 as regional crops. Rice, Japan's main crop, showed a decline from over 2.5 million ha in 1973 to slightly over 1.5 million ha in 2011, while the country's second crop (wheat) was grown steadily on ca. 200,000 ha for the past four decades (ESM 3-Fig. S1). Most of the other 48 crops showed a steady decline in areas under cultivation in the past 50 years (ESM 3-Figs. S2-S6), with the exception of buckwheat (ESM 3-Fig. S2) and several varieties of Brassica rapa (ESM 3-Fig. S3).

The situation is more serious for the 19 crop species that were grown on less than 200 ha in 2010 (ESM 3-Fig. S6). Their areas have declined as more arable land has been used for the major crops. For example, gourds (Lagenaria siceraria L.) have declined from around 3,000 ha in the years after World War II to just above 200 ha in 2012. Some of these crop species are consumed only in Japan, like kuwai (Sagittaria trifolia L.), an indispensable part of traditional Japanese cooking on New Year's Eve (and consumed during the first 3 days of January). Certain varieties of shiso (Perilla frutescens (L.) Britton) and myoga (Zingiber mioga (Thunb.) Roscoe) are distinctive to the Japanese kitchen and demands can only be met by local production, given their perishability. Wasabi roots (Eutrema japonicum (Miq.) Koidz.) are known 
across the world for their role as the pungent accompaniment of sushi. Much of the wasabi that is consumed today, however, is actually horseradish (Armoracia rusticana P.Gaertn., B.Mey. \& Scherb), colored green to look like its rarer counterpart (Smil and Kobayashi 2012). The MAFF data, however, do not provide much data on the different varieties cultivated, so our comparison was largely limited to crop species.

The 59 food crops illustrated in the Seikei Zusetsu catalog (but not listed in the 2016 MAFF surveys) have not been grown in significant quantities in Japan in the last 50 years. However, not all of the 59 species can be considered forgotten. Some are no longer grown in Japan because they can be imported cheaper from other countries (such as sesame), while others are common wild plants that were once grown as vegetables, but are now regarded as weeds, like Capsella bursa-pastoris (L.) Medik., Chenopodium album L., and Taraxacum japonicum Koidz. Some of these species are still harvested from the wild for food and/or medicine (Chen and Qiu 2012), but they are not registered in the MAFF statistics.

\section{Discussion}

\section{Lost Crops and Forgotten Vegetables}

Japan increasingly relies on imports to support its demand for food crops, with a food self-sufficiency rate of 39\% (calorie-wise) in 2013 (Reiher and Yamaguchi 2017). Japan imported USD 19.8 billion worth of vegetable products in 2014, mainly from China and the USA, with the top five commodities being maize, wheat, soybeans, coffee, rapeseed, and frozen and dried vegetables (Simoes 2014). Almost 90\% of soybeans used in Japan come from the USA (63\%), Brazil (18\%), and Canada (16\%).

Less than half of the crop species illustrated in the Seikei Zusetsu catalog are still grown in Japan, and the majority has seen a steady decline in area under cultivation in the past decades. Several of the early nineteenth-century crops appear to be no longer consumed by the Japanese at all. Changes in cultivation practices and land use have led to the drainage of swamps to reclaim more cultivable soils, so marshland crops like Trapa japonica Flerow and Eleocharis kuroguwai Ohwi have disappeared (Von Verschuer and Cobcroft 2016). Still, the persistence of some of these Japanese water plants can be explained by social preferences only. Sagittaria trifolia
L. has fallen out of use in most other societies where it was once an important part of the diet (Garibaldi and Turner 2004). But in Japan, its use in ceremonial dishes has ensured that there is still a demand for this vegetable.

The wide variety of cereals that was grown in early nineteenth-century Japan ensured food security in the country's different climatic regions. Although rice was the preferred grain, the different varieties of millets and barley were essential components of the diet (Smil and Kobayashi 2012). Especially in the northern parts of Japan, where the cool weather and soil conditions were not suitable for rice cultivation, Japanese barnyard millet (Echinochloa esculenta) was an important staple food (Yabuno 1987) and was used for augmenting rice and porridges with a vegetable soup as a flavor base. Post-war affluence, however, has influenced consumption patterns in Japan, prompting a shift away from famine grains like barnyard millet, foxtail millet (Setaria viridis (L.) P.Beauv.), finger millet (Eleusine coracana (L.) Gaertn.), and proso millet (Panicum miliaceum L.), as these grains were considered to be poor people's food (Simoons 1990; Von Verschuer and Cobcroft 2016), with the less nutritious rice being the most favored source of dietary carbohydrates today. However, the acreage devoted to the millet cultivation already started to decrease at the end of the nineteenth century, with the development of cool-weather-resistant rice varieties and the replacement of horses by tractors and automobiles (Yabuno 1987).

Millet may have largely disappeared in Japan, the various species of this small-seeded cereal hold promise in increasing productivity in arid areas elsewhere in the world. Millets are resilient to extreme environmental conditions, such as drought, while their grains are rich in nutrients and lack gluten. Recently, international initiatives have begun to support the improvement of diverse millet types in Africa and India (Tadele 2016).

\section{LANDRACES: LosS OF GENETIC RESOURCES}

The historic crop varieties that are illustrated in the Seikei Zusetsu catalog represent landraces that predate modern breeding. They were developed by traditional Japanese farmers, who adapted them to their local environments and cultural preferences. The open panicles of the early nineteenth-century rice plants, such as the double-headed rice (Seikei Zusetsu catalog vol. 15, p. 22), are characteristic of old varieties. The transition from a spread panicle 
typical of ancestral wild rice (Oryza rufipogon Griff.) to the closed, compact panicle of present cultivars (O. sativa L.) was a crucial event in rice domestication (Zhu et al. 2013). The presence and use of selfsown individuals or "volunteer seedlings," such as the second-growth rice (Seikei Zusetsu catalog vol. 16, p. 40) and soybean (Seikei Zusetsu catalog vol. 18 , p. 22), is a typical feature in traditional agriculture and an importance source of genetic diversity (Elias et al. 2000). Nowadays, most Japanese farmers use seeds that are developed by commercial plant breeders or germplasm institutes and do not store their own seeds for replanting, so it is likely that the majority of the landraces depicted in the Seikei Zusetsu no longer exist.

In many countries, high levels of inter- and intraspecific plant genetic diversity, especially present in traditional crop landraces, are preserved in home gardens (Panyadee et al. 2018). Therefore, it is possible that some of the historic landraces are still grown on small-scale farms or home gardens in Japan. There is evidence of the cultivation of rare landraces of rice, tea, and cucumbers in Japanese home gardens (Kobayashi et al. 2006; Tamaki et al. 2016; Watanabe 2011), but to verify the current existence and conservation status of the historic landraces depicted in the Seikei Zusetsu, a detailed characterization is needed of landraces that are still maintained on Japanese farms, in botanic gardens, and in national gene banks. In one of the few published studies on efforts to recover traditional landraces in Japan, Egashira (2017) recorded 179 landraces in the Yamagata prefecture, of which 154 were vegetables and grains. But time is running out. According to Egashira (2017), the designation "forgotten crop" depends on the collective memory of a certain population that remembers having used the crop at some point, but not using it anymore. This gives a lifespan of roughly two generations (or ca. 100 years) before it becomes nearly impossible to retrace and retrieve viable seeds of the crop.

\section{Breeding Back Japan's Agricultural DIVERSITY}

The high diversity of the turnips and radishes in the Seikei Zusetsu catalog reflect the important role of these Brassicaceae in traditional Japanese agriculture. They are a useful risk mitigation crop, following rice in a rotation scheme and thus able to augment any shortages that might arise from a bad harvest. Some varieties have a delayed maturation, allowing them to overwinter in the field, providing a source of nutrition in the early spring. They store well if dried properly, and can be used in various pickles (tsukemono) to be used in lean periods (Aoba 2013).

The Seikei Zusetsu has already been used in the revival of traditional Brassicaceae in Tokyo. A wellknown example is the "rediscovery" of the shinagawa turnip (Brassica rapa, Seikei Zusetsu catalog vol. 21, p. 33 left), known as shinagawa kabu (品川カブ) as a traditional vegetable in Tokyo (Otake 2009a, b). In a project to subsidize the production and consumption of high addedvalue agricultural products, a research institute in Otsu City (Shiga Prefecture) has successfully revived the Oumi turnip (Brassica rapa, Seikei Zusetsu catalog vol. 21, p. 33 right) from seeds kept at the Shiga Prefecture Agricultural Technology Promotion Center (http://www.city.otsu.lg.jp/ kanko/tokusan/nosui/h28/1488845456526.html, in Japanese).

Several other initiatives on in situ conservation of traditional landraces (often named heirloom varieties) have been taken in Japan. In the northern Yamagata prefecture, traditional landraces are recognized as living cultural treasures, adapted to the long winters that characterize this region (Egashira 2017). Tsuruoka, the only UNESCO city of gastronomy in Japan, is in this prefecture, a recognition deriving to a large extent from the revival of these cultural treasures (UNESCO 2015). Other heirloom varieties that have been promoted recently are edoyasai (江戸野菜), vegetables from Old Tokyo (Otake 2009a), and kyoyasai (京野菜), vegetables from the Kyoto area. The effect of these efforts has been a revival of interest in agriculture, local identity, and the value of the knowledge and practices surrounding food production. These vegetables have acted as catalysts in the revival of agriculture in the regions where they were originally found (Otake 2009a, b). Conservation projects for heirloom crops are more likely to succeed if they add incremental value to certain landraces in selected environments and farming systems, rather than posing as alternatives to modern crops for all farmers (Brush 2008).

\section{Scientific Relevance of the Seikei Zusetsu Catalog}

Our identification of the early nineteenthcentury crop illustrations covers only a small part of the research potential of the Seikei Zusetsu cata$\log$. Though the encyclopedia was produced mainly 
for the benefit of the Satsuma province, it is likely from the contemporary governance structures and scholarly practices that the information in the catalog was not limited by geographic boundaries; rather, it provides a reliable overview of the agricultural practices of the Edo-period Japan (Marcon 2015; Matsui 1975). There is a wealth of agricultural and cultural knowledge described in the 30 volumes that awaits further study. The first 15 volumes deal with topics like land use practices, food preparation, and ceremonies, as well as the variety of agricultural tools that were in use around 1800 . The catalog also offers unique examples of the exchange of knowledge between Dutch and Japanese scientists in the eighteenth and nineteenth centuries. Each plant illustration is accompanied by a long list of both regional and Chinese names, which were outside the scope of the present study. Future agronomic, historic, and linguistic research can help to unearth this common agricultural heritage of China and Japan. The historic landraces, their names, uses, cultivation, and processing methods can serve to stimulate interest in new agrobiodiverse practices in Japan, but can also act as a source of cultural pride. It was this conception that nature studies were inseparable from the economic concerns that made Shigehide's efforts to compile this comprehensive catalog so special, and the reason why it may be of relevance for both scientists and the general public in the twenty-first century.

\section{Conclusions}

The 193 drawings of individual crop varieties in the Seikei Zusetsu catalog represent 109 crop species, of which more than half are no longer cultivated in Japan in quantities to warrant an appearance in the national agricultural statistics. All crops in this catalog represent traditional landraces or heirloom varieties, while most farmers nowadays use cultivars developed by commercial plant breeders or international plant and germplasm research centers, such as IRRI (www. irri.org) and CGIAR (https://www.cgiar.org). The early nineteenth-century crop illustrations represent a genetic variety that is probably lost, although some of these landraces may still be grown on small farms or home gardens. The 30-volume Seikei Zusetsu catalog serves as a repository of valuable knowledge and can act as a gateway to further studies on traditional Japanese crops, agricultural practices, and food processing methods. The work can also stimulate efforts to create more agrobiodiverse farming systems and stimulate the marketing of high-value crops to ensure the survival of distinctive food cultures. Our online presentation of these "lost crops and forgotten vegetables" may help to raise awareness in this process, in and outside Japan, which is a first step in their rehabilitation.

\section{Acknowledgments}

We are grateful to Harm Beukers, Nadia Kreeft, Liesbeth van Wijk, Ben Companjen, and Laurents Sesink of the Leiden University Library for giving us access to the von Siebold collection and designing the web interface of the crop illustrations. Botanists Jos van der Maesen and Brigitta de Wilde-Duyfjes identified the pulses and the cucurbits. Hanneke Jelles and Carla Oldenburger (Hortus Botanicus, Leiden) facilitated the public presentation of this research project. We also thank Eric Schranz for his comments on an earlier version of this paper.

\section{Funding Information}

This research was funded by the Clusius Stichting and Naturalis Biodiversity Center.

Open Access This article is distributed under the terms of the Creative Commons Attribution 4.0 International License (ht t p:// creativecommons.org/licenses/by/4.0/), which permits unrestricted use, distribution, and reproduction in any medium, provided you give appropriate credit to the original author(s) and the source, provide a link to the Creative Commons license, and indicate if changes were made.

\section{Literature Cited}

Aoba, T. 1981. 野菜一在来品種の系譜. 東京: 法政大学出版局 (Vegetables: Genealogies of traditional varieties, in Japanese). Tokyo: Hosei University Press. . 2013. 日本の野菜文化史事典 (Japan's vegetables: A historical record, in Japanese). Tokyo: Yasaka Publishing.

Beal, S. 2000. Si-Yu-Ki Buddhist records of the Western world: Translated from the Chinese of Hiuen Tsiang (A.D. 629). Oxford: Routledge.

Beekman, E. M. 2011. The Ambonese herbal by Georgius Everhardus Rumphius. New Haven, Connecticut: Yale University Press.

Brown, Y. Y. 1975. The Von Siebold collection from Tokugawa, Japan. The British Library Journal 1(2):38-55. 
Brush, S. B. 2008. Farmers' bounty: Locating crop diversity in the contemporary world. New Haven, Connecticut: Yale University Press.

Burns, S., G. Fujiwara, and P. Nosco. 2007. The Kokugaku (Native Studies) School. In: The Stanford Encyclopedia of Philosophy, ed., E. N. Zalta. Stanford, California: Metaphysics Research Lab, Stanford University. https://plato. stanford.edu/archives/fall2008/entries/ kokugaku-school/

Casals, J., F. Casañas, and J. Simó. 2017. Is it still necessary to continue to collect crop genetic resources in the Mediterranean area? A case study in Catalonia. Economic Botany 71(4): 330-341.

Chen, B. and Z. Qiu. 2012. Consumers' attitudes towards edible wild plants: A case study of Noto Peninsula, Ishikawa Prefecture, Japan. International Journal of Forestry Research, Article ID 872413. https://doi.org/10.1155/2012/ 872413.

Crosby, A. W. 2003. The Columbian exchange: Biological and cultural consequences of 1492. Santa Barbara, California: ABC-CLIO.

Dodoens, R. 1644. Cruijdeboeck. Antwerp: Balthasar Moretus.

Egashira, H. 2017. 山形の在来作物. 環境保 全 (山形大学環境保全センタ一). Landraces of Yamagata Prefecture. Environmental Preservation 20:27-52. http://www.id.yamagata-u.ac. jp/EPC/21 kouhou/no20s.pdf

Elias, T. S. and P. A. Dykeman. 2009. Edible wild plants: A North American field guide to over 200 natural foods. New York: Sterling Publishing.

Elias, M., O. Panaud, and T. Robert. 2000. Assessment of genetic variability in a traditional cassava (Manihot esculenta Crantz) farming system, using AFLP markers. Heredity 85(3):219-230.

Fukuoka, M. 2012. The premise of fidelity: Science, visuality, and representing the real in nineteenth-century Japan. Stanford, California: Stanford University Press.

Garibaldi, A. and N. Turner. 2004. Cultural keystone species: Implications for ecological conservation and restoration. Ecology and Society 9(3): 1. http://www.ecologyandsociety.org/vol9/iss3/ art1

Kauffmann Jokl, D. H. and F. Hiyama. 2003. Philipp Franz von Siebold: A medical pioneer of the 250-year Holland-Japan legacy. Archives of Ophthalmology 121(4):562-565.
Khoury, C. K., A. D. Bjorkman, H. Dempewolf, J. Ramirez-Villegas, L. Guarino, A. Jarvis, L. H. Rieseberg, and P. C. Struik. 2014. Increasing homogeneity in global food supplies and the implications for food security. Proceedings of the National Academy of Sciences 111(11): 4001-4006.

Kobayashi, A., K. Ebana, S. Fukuoka, and T. Nagamine. 2006. Microsatellite markers revealed the genetic diversity of an old Japanese rice landrace 'Echizen'. Genetic Resources and Crop Evolution 53(3):499-506.

Liebman, M. and L. A. Schulte. 2015. Enhancing agroecosystem performance and resilience through increased diversification of landscapes and cropping systems. Elementa: Science of the Anthropocene 3(41). https://doi.org/10.12952/ journal.elementa.000041.

Lin, B. B. 2011. Resilience in agriculture through crop diversification: Adaptive management for environmental change. BioScience 61(3):183193.

MAFF, Japan Ministry of Agriculture Forestry, and Fisheries. 2016a. Overview of areas under cultivation of major arable crops, 作況調査 (水陸 稲、麦類、豆類、玑儿上、飼料作 物、工芸農作物) : 農林水産省. http://www. maff.go.jp/j/tokei/kouhyou/sakumotu/ sakkyou_kome/index.html (1 September 2018)

- 2016b. Overview of areas under cultivation of vegetables 作物統計調査 作況調 査(野菜) 長期累年|ファイルから探す| 統計デー夕を探す| 政府統計の総合空口. Retrieved from https://www.e-stat.go.jp/ statsearch $/$ files ? page $=1 \&$ layout $=$ datalist \&toukei $=00500215 \&$ tstat $=$ $000001013427 \&$ cycle $=0 \&$ tclass $1=$ $000001032286 \&$ tclass $2=000001037845$

September 2018)

Marcon, F. 2015. The knowledge of nature and the nature of knowledge in early modern Japan. Chicago: University of Chicago Press.

Matsui, M. 1975. Shimazu Shigehide 1745-1833: A case study of Daimyo leadership. Ph.D. thesis, University of Hawaii

Mazzola, P., F. M. Raimondo, and R. Schicchi. 2003. The agro-biodiversity of Sicily in ancient herbaria and illustrated works. Bocconea 16(1): 311-21.

Nosco, P. 1998. Confucian philosophy, Japanese. Routledge Encyclopedia of Philosophy. Oxford, United Kingdom: Routledge. https://doi.org/ 10.4324/9780415249126-G103-1. 
Nylandt, P. 1673. Der Nederlandsche Herbarius of Kruydt-boeck. Amsterdam: Marcus Doornick.

Oldfield, M. L. and J. B. Alcorn. 1991. Biodiversity: Culture, conservation, and ecodevelopment. Boulder, Colorado: Westview.

Otake, M. 2009a. 江戸東京野菜 図鑑篇. 東京: 農山漁村文化協会. Edo-Tokyo vegetables: An illustrated encyclopedia. Tokyo: Rural Culture Association (Nobunkyo).

Otake, T. 2009b. Cultivating pure tastes from the past. The Japan Times Online. http:// www.japantimes.co.jp/life/2009/12/20/general/ cultivating-pure-tastes-from-the-past/ (3 January 2019).

Panyadee, P., H. Balslev, P. Wangpakapattanawong, and A. Inta. 2018. Karen homegardens: Characteristics, functions, and species diversity. Economic Botany 72(1):1-19.

PROSEA. 1992-2003. Plant resources of SouthEast Asia, 19 volumes. Wageningen: Backhuys Publishers.

Reiher, C. and T. Yamaguchi. 2017. Food, agriculture and risk in contemporary Japan. Contemporary Japan, 29(1):2-13. https://doi.org/10. 1080/18692729.2017.1256967.

Rutto L. K., V.W. Temu, and M. S. Ansari. 2016. Genetic vulnerability and crop loss: The case for research on underutilized and alternative crops. In: Mathematical sciences with multidisciplinary applications, ed., B. Toni, 465-479. New York: Springer.

Shimizu, M. 1987. Lilies of Japan (English summary). In: The lilies of Japan, species and hybrids (In Japanese), ed., M. Shimizu, 116-121. Tokyo: Seibundo-shinkosha.

Simoes, A. 2014. The observatory of economic complexity: What does Japan import (2014)? https://atlas.media.mit.edu/en/visualize/tree_ map/hs92/import/jpn/all/show/2014/ (3 January 2019).

Simoons, F. J. 1990. Food in China: A cultural and historical inquiry. Boca Raton, Florida: CRC Press.

Skuncke, M. C. 2014. Carl Peter Thunberg: Botanist and physician. Uppsala: Swedish Collegium for Advanced Study (SCAS).

Smil, V. and K. Kobayashi. 2012. Japan's dietary transition and its impacts. Cambridge, MA: The MIT Press.
Tadele, Z. 2016. Drought adaptation in millets. In: Abiotic and biotic stress in plants: Recent advances and future perspectives, eds., A. Chanker and S. Chanker, 639-662. London: Intech Open.

Tamaki, I., T. Kuze, K. Hirota, and M. Mizuno. 2016. Genetic variation and population demography of the landrace population of Camellia sinensis in Kasuga, Gifu Prefecture, Japan. Genetic Resources and Crop Evolution 63(5):823831.

Thunberg, C. P. 1784. Flora Japonica. Leipzig, Germany: I. G. Müller.

UNESCO. 2015. Tsuruoka: Creative cities network. United Nations Educational, Scientific and Cultural Organization. https://en.unesco. org/creative-cities/tsuruoka (3 January 2019).

Van Sant, J. E. 2012. Rangaku medicine and "foreign" knowledge in late Tokugawa Japan. Southeast Review of Asian Studies 34:207-214.

Villa, T. C. C., N. Maxted, M. Scholten, and B. Ford-Lloyd. 2005. Defining and identifying crop landraces. Plant Genetic Resources 3(3): 373-384.

Von Verschuer, C. and W. Cobcroft. 2016. Rice, agriculture, and the food supply in premodern Japan. New York: Routledge.

Watanabe, S. 2011. Reviving recipes. Documentary, published on https://www.youtube.com/ watch?v=oZDzsRET-i8 . Yamagata, Japan: Takahashi Takuya.

Yabuno, T. 1987. Japanese barnyard millet (Echinochloa utilis, Poaceae) in Japan. Economic Botany 41(4):484-493.

Zeven, A. C. 1998. Landraces: A review of definitions and classifications. Euphytica 104(2):127139.

Zeven, A. C. and W. A. Brandenburg. 1986. Use of paintings from the 16th to 19 th centuries to study the history of domesticated plants. Economic Botany 40(4):397-408.

Zhu, Z., L. Tan, Y. Fu, F. Liu, H. Cai, D. Xie, F. Wu, J. Wu, T. Matsumoto, and C. Sun. 2013. Genetic control of inflorescence architecture during rice domestication. Nature Communications 4, Article number 2200. 